\title{
Pelatihan Instalasi dan Penataan Sistem Tata Suara Masjid
}

\section{Mochammad Taufik ${ }^{1}$, Hudiono ${ }^{2}$, Aisah ${ }^{3}$, Aad Hariyadi ${ }^{4}$, Ridho Hendra Yoga \\ Perdana ${ }^{5}$, Amalia Eka Rakhmania ${ }^{*}$}

1,3,4,5,6 Program Studi Teknik Telekomunikasi, Jurusan Teknik Elektro, Politeknik Negeri Malang, Jalan Sukarno Hatta No. 9, Malang, Provinsi Jawa Timur, Indonesia.

2 Program Studi Jaringan Telekomunikasi Digital, Jurusan Teknik Elektro, Politeknik Negeri Malang, Jalan Sukarno Hatta No. 9, Malang, Provinsi Jawa Timur, Indonesia.

Corresponding Email: amaliaeka.rakhmania@polinema.ac.id 6.

\section{Article History:}

Received: Jul 23th 2021

Revised: Aug 14th 2021

Accepted: Aug 17th 2021

Keywords: Mosque, Training; Takmir; Sound System.
Abstract: Mosques are one of the places where community activities are concentrated in the religious field, especially in Indonesia where the majority of the population is Moslems. The mosques are also important means of spreading religion, due to the close location and spread out in the community. The arrangement of the sound system in a mosque is one of the vital things to support religious activities. The purpose of this activity is to provide training on the installation and arrangement of sound systems at the Darul Muttaqin Mosque, Kedungkandang District, Malang. Training is given to mosque takmirs so that they can install and maintain sound systems in mosques. The result of this training was that the sound system of the mosque which was initially bad due to a buzzing sound and did not clearly convey the information provided became clearer and no longer disturbed the congregation or local residents. When there is a sound system problem, takmir can repair it directly without the need to wait for a technician so that religious activities and messages run smoothly. 


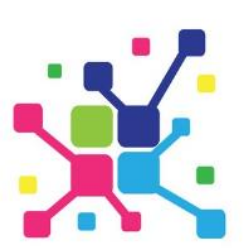

\section{Pendahuluan}

Saat ini di Indonesia terdapat 800.000 masjid, jumlah bangunan tersebut merupakan jumlah terbanyak di seluruh dunia [1]. Namun ada ribuan masjid di Indonesia yang dinyatakan tidak mempunyai peralatan sistem pengeras suara yang mumpuni. Suara Adzan dan khotbah yang terdengar dinilai pecah, sember, cempreng, krasak-kresek atau bahkan hilang-timbul. sehingga tidak jelas, atau terdengarnya keras tapi tak jelas artikulasi bicaranya, atau ada gangguan-gangguan seperti dengung dan lain-lain yang mengganggu suara khatib. Boleh jadi, itulah anggapan umum masyarakat tentang buruknya kualitas sistem pengeras suara yang ada di sebagian besar masjid yang ada di Indonesia. Padahal, kualitas sistem pengeras suara akan sangat menentukan konsentrasi jamaah masjid yang ada di dalam masjid.

Menurut Jusuf Kala sebagai Ketua Dewan Masjid Indonesia (DMI), ada 75 persen dari seluruh masjid di Indonesia yang sistem pengeras suaranya tidak bagus [2] sehingga hanya dalam jarak beberapa meter saja, sudah tidak terdengar apa yang disampaikan oleh khatib ataupun oleh muadzin. Bahkan ada beberapa yang suaranya cempreng dan membuat panggilan sholat atau khotbah ini terasa tidak merdu di telinga. Hal ini dapat terjadi karena pemasangan tata letak speaker yang kurang tepat dan ruang akustik yang kurang baik [3]. Apalagi bila masjid yang dibangun dengan dinding marmer dan kaca, suara akan memantul, sehingga sulit untuk di dengar, akibatnya jamaah tidak bisa mendengarkan dengan maksimal.

Selain peralatan yang tata suara yang memadai dalam pengoperasian sehari- hari perlu pengelolaan peralatan sound system dengan baik. Penanganan peralatan oleh tenaga operator yang tidak terampil bisa mengakibatkan buruknya suara yang dihasilkan [4] seperti suara distorsi atau clipping, sering timbul feedback saat digunakan. Hal yang lebih buruk lagi adalah sering rusaknya peralatan sound system seperti loudspeaker ataupun amplifier. Rusaknya peralatan tersebut bisa disebabkan oleh tidak tepatnya setting peralatan oleh operator atau bisa juga karena salah dalam disain awal [5].

Kondisi akustik yang baik dalam ruang dengan fungsi yang spesifik seperti halnya masjid dewasa ini bukan lagi sebuah kemewahan (luxury), tetapi kebutuhan (necessity). Di dalam ruang masjid misalnya bila khatib memberikan khotbah, jika suaranya tidak dapat didengar dengan jelas oleh setiap jamaah di seluruh ruangan, maka jamaah tidak memberikan perhatian dan cenderung mengantuk atau berbisik-bisik. Keadaan ini jelas tidak diinginkan karena pesan moral tidak dapat ditangkap dengan sempurna oleh para jamaah. Begitu pula pada shalat berjamaah, suara imam yang tidak jelas dapat mengganggu kekhusukan ibadah, bahkan dapat merusak kesempurnaan ibadah. Oleh sebab itu kondisi akustik ruang masjid seharusnya mendapatkan perhatian khusus [6].

Karena akan sangat mahal untuk mengubah desain struktur masjid, maka masjid sebagai media publik harusnya didukung oleh sistem pengeras suara yang cukup dan baik. Cukup dalam arti level suara dapat di dengar seluruh jamaah. Sedangkan baik 


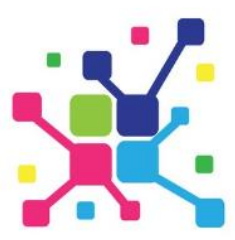

artinya artikulasi pembicaraan dapat terbaca. Penguat suara yang dibutuhkan adalah penguat yang baik untuk rentang frekuensi suara vokal baik untuk adzan, iman atau pengajian.

Untuk menghasilkan tata suara masjid/musholla yang baik perlu perencanaan yang baik pula. Perencanaan yang baik harus dikembangkan berdasarkan kondisi real masjid dan mushola seperti luas, bentuk bangunan dan lain sebagainya. Setiap masjid/ruang adalah unik dari segi akustik, sehingga harus dicoba berbagai alternatif pemasangan speaker untuk menghasilkan kualitas suara yang optimal dan minim gangguan [7]. Kriteria sound system yang baik untuk tempat ibadah seperti masjid diantaranya adalah, suara keluaran yang bersih, bebas dari noise atau derau,pengaturan nada bass dan treble yang pas sehingga enak didengar oleh telinga,memiliki penyebaran tingkat kekerasan suara yang baik terutama untuk daerah disekitar gedung baik didalam masjid maupun disekeliling masjid [8].

Pergantian instalasi sound system lama [9,10], perancangan audio mixer [11], desain active crossover untuk menggantikan tone control [12], implementasi fpga untuk desain sistem audio [13], perancangan tata suara dengan mempertimbangkan parameter ruang akustik [14], maupun pemberian pelatihan [8] adalah langkah teknis maupun nonteknis yang dapat dilakukan untuk memperbaiki kualitas sistem tata suara di dalam masjid.

Dari data potensi kegiatan Keagamaan Masyarakat di kelurahan Buring, kecamatan Kedungkandang dalam kaitannya dengan pelaksanaan kegiatan keagamaan di Masjid Darul Muttaqin, kondisi tata suara mengalami permasalahan, di mana suara yang dikeluarkan tidak jelas sehingga masyarakat kurang bisa memahami pengumuman yang dikeluarkan melalui system tata suara masjid. Kegiatan yang diadakan di masjid menjadi kurang lancar karena kurang baiknya system tata suara masjid. Bahkan terkadang, masjid perlu menyewa sound system dari luar untuk digunakan pada acaraacara tertentu, sehingga menambah pengeluaran dari kas masjid yang seharusnya bisa digunakan untuk kegiatan keagamaan lainnya.

Untuk itulah perlu diberikan pelatihan penataan sistem pengeras suara masjid khususnya bagi pengurus masjid agar sistem pengeras suara masjid dapat menghasilkan suara jernih dan detil, artikulasi ucapan harus terdengar jelas. Hal ini diharapkan karena sistem pengeras suara yang terpasang nantinya bisa meminimalkan feedback yang timbul akibat mic, tidak ada noise, tidak terlalu besar level bass, suara mic tidak terdengar hanya frekuensi tinggi saja yang dihasilkan.

\section{Metode}

a. Metode Pelaksanaan Kegiatan

Metode yang digunakan dalam kegiatan ini adalah pelatihan, melalui demonstrasi 
penataan dan instalasi sistem tata suara sehingga takmir masjid dapat memiliki kemampuan tersebut. Pelaksanaan kegiatan ini terbagi menjadi 4 tahap utama.

1) Tahap pertama dalam melakukan pelatihan adalah dengan survey lokasi speaker yang terdapat di mitra. Observasi di lapangan dilaksanakan untuk mempermudah pemilihan parameter spesifikasi perangkat yang akan digunakan untuk desain dan instalasi.

2) Tahap kedua adalah merancang sistem tata suara yang nantinya digunakan sebagai bahan pelatihan. Kajian dan analisa data lokasi dan ruang digunakan sebagai dasar perencanaan perangkat dan desain peletakan sistem tata suara. Kami melibatkan mitra dalam proses perencanaan supaya desain sesuai dengan kebutuhan kegiatan yang biasa dilakukan di lokasi mitra.

3) Tahap ketiga adalah melakukan instalasi sekaligus pelatihan kepada para takmir masjid di lokasi mitra. Instalasi dilakukanoleh teknisi, sembari menjelaskan proses dan apa saja yang perlu dilakukan dalam proses instalasi.

4) Tahap keempat adalah pengujian kemampuan perangkat tata suara yang telah terpasang. Di sini penjelasan cara pengujian juga diberikan kepada mitra, termasuk troubleshooting sistem dan cara perawatan sistem tata suara supaya dapat bekerja dengan baik dalam waktu yang lama.

b. Waktu Efektif Pelaksanaan Kegiatan

Pelaksanaan kegiatan ini dilakukan secara efektif mulai bulan Juli-Agustus tahun 2020.

c. Tempat Kegiatan

Mitra pada program pengabdian kepada Masyarakat ini adalah Masjid Darul Muttaqin yang terletak di Kecamatan Kedungkandang, Kota Malang. Masjid yang telah dibangun sejak tahun 1917 di tanah seluas 360m² ini memiliki kapasitas 500 orang. Kegiatan di lingkungan masjid cukup beragam, mulai dari pemberdayaan zakat, infaq, shodaqoh dan wakaf, menyelenggarakan kegiatan pendidikan (TPA, madrasah, pusat kegiatan belajar masyarakat), menyelenggarakan pengajian rutin, menyelenggarakan dakwah Islam/tabliq akbar, menyelenggarakan kegiatan hari besar Islam, menyelenggarakan sholat jumat, dan menyelenggarakan ibadah sholat fardhu setiap hari. 


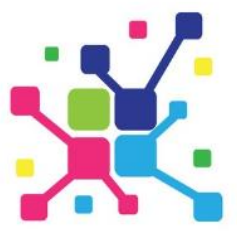

A J A D

Jurnal Pengabdian kepada Masyarakat

Vol. 1, No. 2, October, 2021, pp. 69-76 DOI : https://doi.org/10.35870/ajad.v1i2.15

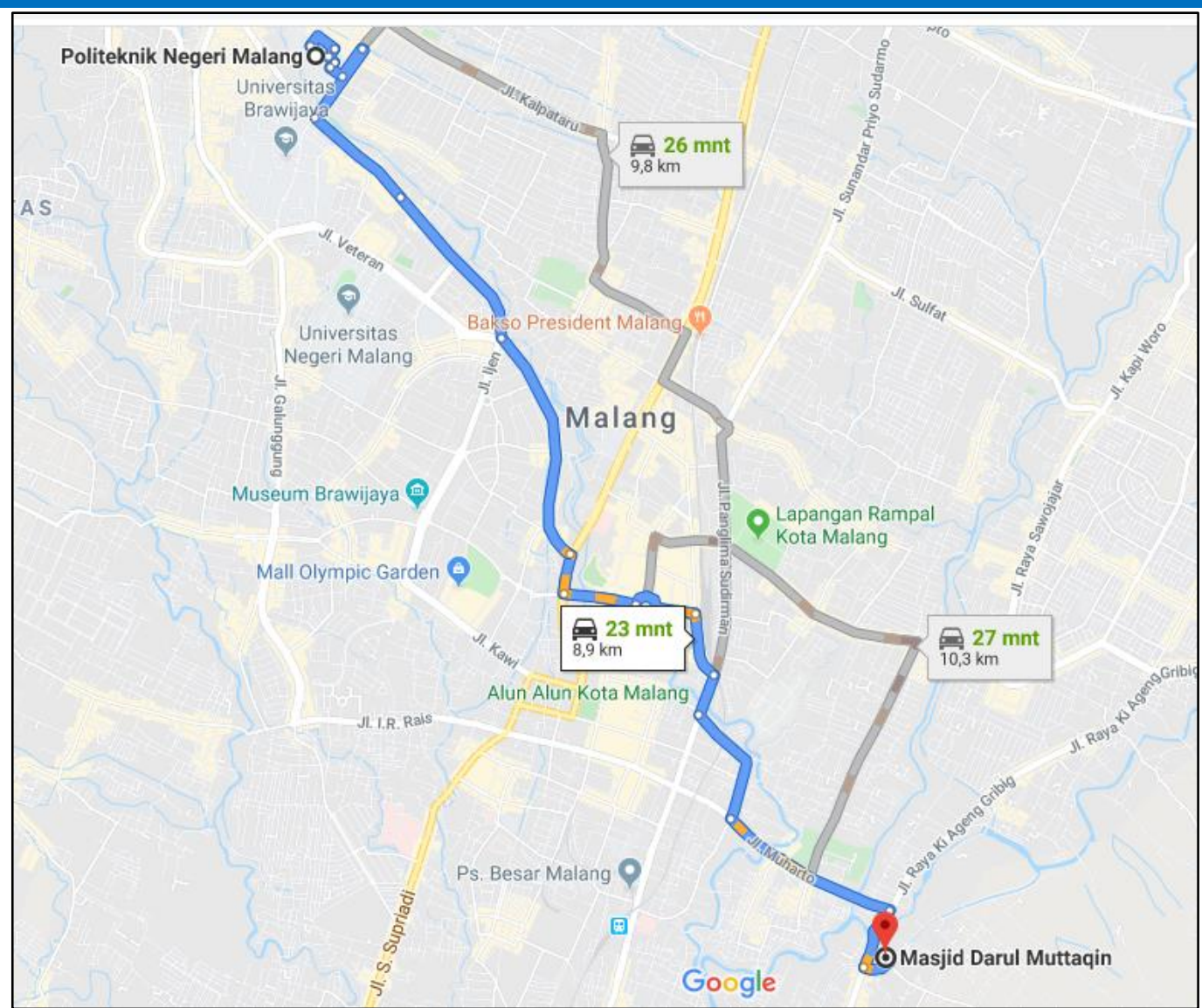

Gambar 1. Map dan Jarak Lokasi Kegiatan.

\section{Hasil}

Hasil pengabdian kepada masyarakat yang telak dilakukan menunjukkan adanya peningkatan kemampuan takmir masjid untuk melakukan instalasi, troubleshooting, dan maintenance peralatan tata suara dari yang semula tidak bisa dan menjadi sangat mudah.

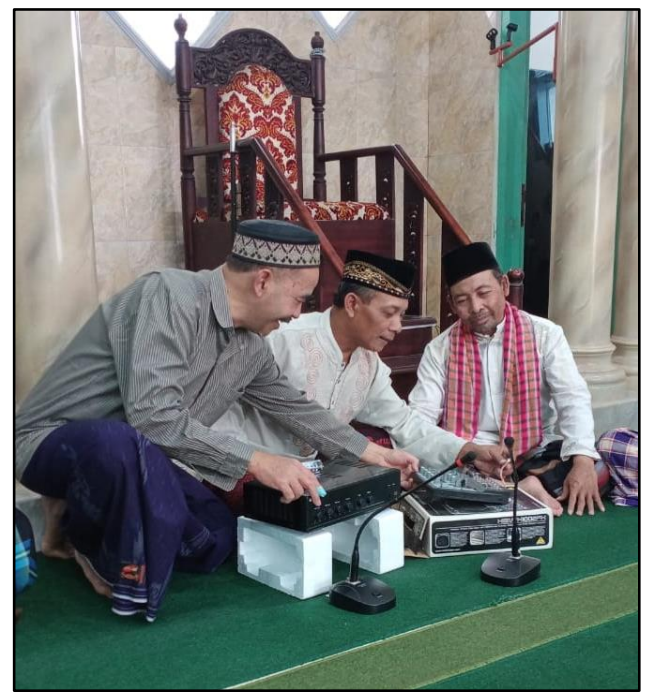

Gambar 2. Pelatihan penggunaan sistem tata suara masjid 

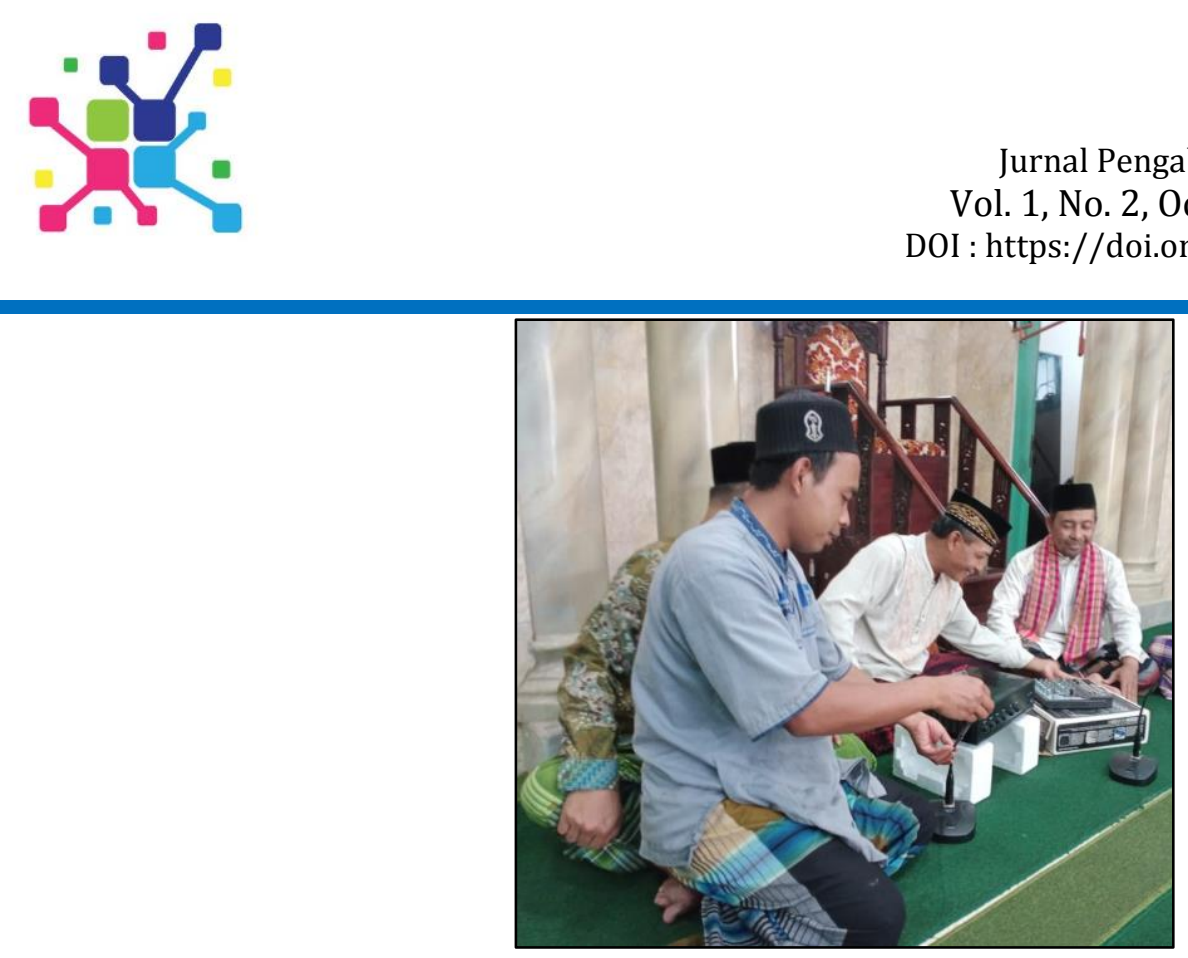

Gambar 3. Takmir masjid mencoba sistem tata suara dan mempelajari masingmasing peralatan

Para takmir masjid diberikan daftar kemungkinan permasalahan yang mungkin terjadi dalam sistem tata suara masjid, misalnya ketika suara yang dihasilkan kurang jelas, bisa jadi setting echo pada mixer terlalu berlebihan [10]. Suara khatib yang terkadang pecah juga dapat terjadi karena kualitas mikrofon dan koneksi kabel yang kurang baik. Sebelumnya, digunakan mikrofon clip on, padahal mikrofon ini merupakan salah satu sumber feedback karena dapat menangkap suara dari segala arah [15]. Oleh karena itu, pada kegiatan ini dipilihkan mikrofon biasa dan kabel yang berkualitas baik serta pemasangan koneksi kabel yang diperhatikan supaya tidak menghasilkan noise bagi informasi yang diberikan.

Takmir juga diberi informasi cara mengatur equalizer pada mixer untuk menghindari suara tajam yang dihasilkan. Selain kemampuan takmir masjid yang meningkat, $100 \%$ jamaah masjid menyatakan bahwa terdapat peningkatan kualitas suara yang dihasilkan dari perancangan dan instalasi sistem tata suara yang baru. Dengan sistem yang semula, suara yang terdengar kurang jernih, pecah, bahkan terputus-putus dan terdapat noise berdengung maupun suara terputus-putus. Dari luar masjid, suara yang disampaikan mengganggu sekitar karena adanya permasalahan tersebut. Dengan adanya desain tata suara yang baru, suara yang dihasilkan menjadi lebih jelas dan bebas feedback, baik didengar dari dalam masjid maupun dari luar masjid, sehingga tidak lagi mengganggu lingkungan sekitar. Pelaksanaan kegiatan dan syiar keagamaan menjadi lebih lancar.

\section{Kesimpulan}

Pelatihan yang telah dilaksanakan mampu menghasilkan penataan dan instalasi sistem tata suara yang lebih baik dari segi pemilihan komponen, lokasi peletakan sistem, serta pengaturan variabel-variabel pada komponen di Masjid Darul Muttaqin. Peningkatan keterampilan dan pemahaman takmir masjid mengenai sistem tata suara 
yang telah diberikan juga meningkat sehingga dapat melakukan perbaikan sendiri apabila terjadi permasalahan ringan. Masyarakat sekitar masjid menyetujui bahwa pelatihan ini memberikan dampak positif yang menjadikan kegiatan dan syiar keagamaan berjalan lebih lancar.

\section{Daftar Referensi}

[1] Rezkisari. 2020. Jumlah Masjid Indonesia Terbanyak di Dunia. https://republika.co.id/berita/q6d8ij328/jumlah-masjid-indonesia-terbanyakdi-dunia. 28 Februari 2020 (04:03).

[2] Serambi Indonesia. 2020. 75 Persen Sound system Masjid Kualitasnya Buruk, Jusuf Kalla Ingin Lakukan Perbaikan. https://aceh.tribunnews.com/2020/07/08/75persen-sound-system-masjid-kualitasnya-buruk-jusuf-kalla-ingin-lakukanperbaikan. 8 Juli 2020 (23:29).

[3] Nugraha, Y., 2020. Analisis Perbandingan Tingkat Tekanan Bunyi Terhadap Sistem Pembangkit Suara Akustik dengan Efek Surround dan Tanpa Efek Surround. STRING (Satuan Tulisan Riset dan Inovasi Teknologi), 5(2), pp.201-209.

[4] Oskandar, D., Palawi, A. and Nurlaili, N., 2019. TATA TEKNIK SUARA MUSIK GARAPAN ETNIK DALAM SEREMONIAL PEMBUKAAN PKA 7.Jurnal Ilmiah Mahasiswa Pendidikan Seni, Drama, Tari \& Musik, 4(3).

[5] Supriyadi, T., Solihin, R., Slameta, R. and Setiadi, B., 2020. Analisis Terhadap Sering Rusaknya Loudspeaker Di Masjid Luqmanul Hakim Polban. Jurnal DIFUSI, 3(2), pp.64-64.

[6] Mariani, M. and Rauf, N., 2007. Deskripsi Kondisi Akustik Ruang Masjid Al Markaz Al Islami Makassar. SMARTek, 6(4).

[7] EKo Saputro. 2021. Installasi sound system di masjid. https://docplayer.info/151422951-Installasi-sound-system-di-masjid-bagian1.html. 11 Mei 2021 (13:21).

[8] Zulfikar, Z., 2019. Pelatihan Perakitan Sound Sistem Masjid Untuk Remaja Masjid Al-Bayan Komplek Politeknik Negeri Lhokseumawe. In Prosiding Seminar Nasional Politeknik Negeri Lhokseumawe (Vol. 3, No. 1).

[9] Riyanto, D. and Munaji, M., 2018. IbM PENGERAS SUARA MASJID DARUSALAM JANTI SLAHUNG. Jurnal Dedikasi Masyarakat, 2(1), pp.30-36.

[10] Basuki, A., 2017. Perancangan Sistem Tata Suara Masjid Al Aqsha SukodonoSidoarjo (Doctoral dissertation, Institut Teknologi Sepuluh Nopember). 
[11] Rehena, N.S., Mamahit, D.J., Wuwung, J.O. and Narasiang, B.S., 2014. Rancang Bangun Audio mixer Yang Dilengkapi Dengan Desibel Peak Meter. Jurnal Teknik Elektro dan Komputer, 3(2), pp.10-18.

[12] Riyanto, A., Arifa, W. and Salim, S.A., 2019. Rancang Bangun Sistem Audio (Sound system) Menggunakan Rangkaian Crossover Aktif dengan Tiga Jalur Frekuensi. Jurnal Vokasi, 14(1), pp.1-8.

[13] Baskhoro, O.B., 2018. Pengarah Suara pada Sistem Audio Berdasarkan Beda Phasa (Doctoral dissertation, Institut Teknologi Sepuluh Nopember).

[14] Santoso, T., Soegiarto, J.B. and Budhiantho, M.H., 2014. Perancangan Tata Suara Balairung Utama Universitas Kristen Satya Wacana, Salatiga. Techné: Jurnal Ilmiah Elektroteknika, 13(02), pp.167-172.

[15] J. Sarwono, K. Panggulu, and A. S. Sudarsono., 2018. Panduan pelatihan akustik masjid, Bandung. 